\title{
American Society of Mammalogists
}

Reproductive Biology of the Red-Giant Flying Squirrel, Petaurista petaurista, in Taiwan Author(s): Pei-Fen Lee, Yao-Sung Lin, Donald R. Progulske

Source: Journal of Mammalogy, Vol. 74, No. 4 (Nov., 1993), pp. 982-989

Published by: American Society of Mammalogists

Stable URL: http://www.jstor.org/stable/1382437

Accessed: 16/05/2009 03:37

Your use of the JSTOR archive indicates your acceptance of JSTOR's Terms and Conditions of Use, available at http://www.jstor.org/page/info/about/policies/terms.jsp. JSTOR's Terms and Conditions of Use provides, in part, that unless you have obtained prior permission, you may not download an entire issue of a journal or multiple copies of articles, and you may use content in the JSTOR archive only for your personal, non-commercial use.

Please contact the publisher regarding any further use of this work. Publisher contact information may be obtained at http://www.jstor.org/action/showPublisher?publisherCode=asm.

Each copy of any part of a JSTOR transmission must contain the same copyright notice that appears on the screen or printed page of such transmission.

JSTOR is a not-for-profit organization founded in 1995 to build trusted digital archives for scholarship. We work with the scholarly community to preserve their work and the materials they rely upon, and to build a common research platform that promotes the discovery and use of these resources. For more information about JSTOR, please contact support@jstor.org. 


\title{
REPRODUCTIVE BIOLOGY OF THE RED-GIANT FLYING SQUIRREL, PETAURISTA PETAURISTA, IN TAIWAN
}

\author{
Pei-Fen Lee, Yao-Sung Lin, and Donald R. Progulske \\ Department of Zoology, National Taiwan University, \\ Taipei, Taiwan, Republic of China (PFL and YSL) \\ Department of Forestry and Wildlife Management, \\ University of Massachusetts, Amherst, MA 01003 (DRP)
}

\begin{abstract}
Reproductive characteristics of red-giant flying squirrels (Petaurista petaurista) were studied from December 1981 to November 1982 in Taiwan. We collected 216 adults (116 males, 100 females) and 65 immatures ( 23 males, 42 females). The sex ratio of adults did not deviate from 1:1 ratio $(P>0.05)$. Adult females tended to be heavier than adult males (1,334 and $1,260 \mathrm{~g}$, respectively, $P<0.01)$, but the sexes showed no differences in other body characteristics. Some males maintained reproductive capacity in all months except February, and most were sexually active in March-June and October-November. Most females were sexually active in May-July and November-January. About one-half of the adult females (49\%) became pregnant during each breeding season, in winter (DecemberFebruary) and summer (June-August). Pregnancy rates ranged from 50 to $57 \%$ in all months except February. Litter sizes ranged from one to two, with an average of 1.04 young/litter. The estimated birth weight for $P$. petaurista was $>56 \mathrm{~g}$. This species is a seasonal breeder with low reproductive rates, which may be a result of a low predation rate combined with their high degree of folivory.
\end{abstract}

Key words: Petaurista, reproduction, flying squirrel, Taiwan

Giant flying squirrels (Petaurista) are nocturnal arboreal folivores that reside in tree cavities during the daytime (Muul and Lim, 1978; Nowak and Paradiso, 1983). They are widely distributed in eastern and southeastern Asia (Honacki et al., 1982). Five species are recognized (Nowak and Paradiso, 1983); white-cheeked giant flying squirrels ( $P$. leucogenys), giant flying squirrels ( $P$. magnificus), spotted giant flying squirrels ( $P$. elegans), red-giant flying squirrels ( $P$. petaurista), and white-faced giant flying squirrels ( $P$. alborufus).

Little is known of the reproductive biology of Petaurista sp. (Lin et al., 1985), except for some scattered reports on litter sizes (Kuroda, 1940; Medway, 1978; Mitchell, 1979; Muul and Lim, 1978; Udagawa, 1954). $P$. petaurista ranges from the Himalayas across southern China to Taiwan, southward to Sri Lanka, and eastward into
Borneo (Askins, 1977). Distributed from 300 to $2,200 \mathrm{~m}$ in mountainous areas in Taiwan, $P$. petaurista is most abundant in the lower elevations of hardwood forests and recently has adapted to secondary conifer plantations, where it has become a pest species (Lee et al., 1986; Lin and Lee, 1986).

In an effort to address some forest-management issues, we initiated a series of ecological studies on giant flying squirrels. We found that $P$. petaurista was able to explore secondary conifer plantations and use this habitat as feeding and resting areas (Lee et al., 1986), and we studied bark-stripping behavior of $P$. petaurista on Japanese fir (Cryptomeria japonica-Lin and Lee, 1986). $P$. petaurista is most active before midnight and home ranges of adult females in conifer plantations was estimated to be 3.2 ha (Lin et al., 1988). The average density of $P$. petaurista is 2.35 and $0.56 / 10$ ha in hardwood 
and conifer plantations, respectively (Lee et al., 1993).

A proposed management strategy was to shoot the squirrels in conifer plantations (W. E. Howard, pers. comm.). Although this practice may prove useful, it was not clear how hunting affects squirrel populations because no detailed reproductive information is available. In this paper, we document the reproductive characteristics of $P$. petaurista, particularly the seasonal breeding patterns of males and females.

\section{Materials AND Methods}

We collected squirrels in hardwood forests near Sunmin Village of southern Taiwan $\left(23^{\circ} 13^{\prime} \mathrm{N}\right.$, $120^{\circ} 41^{\prime} \mathrm{E}$ ) between December 1981 and November 1982. At an elevation of $500 \mathrm{~m}$, Sunmin has a yearly mean temperature of $20.8^{\circ} \mathrm{C}(\bar{X}$ summer $=25^{\circ} \mathrm{C}$; winter $=15^{\circ} \mathrm{C}$ ). Precipitation, ca. 3,000 $\mathrm{mm}$ annually, occurs mostly between March and August, while other months are dry. Most hardwood trees are members of the families Lauraceae and Fagaceae. These trees provide abundant nuts and other food for squirrels.

Each squirrel was weighed on a custom-built spring scale accurate to $0.1 \mathrm{~g}$. The lengths of body, tail, ear, hind foot, and styliform cartilage were measured to the nearest $1 \mathrm{~mm}$. Paired testes and epididymides were weighed to the nearest $10 \mathrm{mg}$. Testes were preserved in Bouin solution, later transferred to $70 \%$ alcohol, and serially sectioned at 6-8 $\mu \mathrm{m}$. Sections taken from the middle of testes were used to measure diameters of seminiferous tubules. Two diameters from each tubule were measured by an ocular micrometer. An average of 10 measurements for each animal was taken as the diameter of the seminiferous tubule of the squirrel, as recommended by Pudney (1976). The presence of enlarged nipples was recorded for females. Both ovaries and uteri were removed from the body and weighed to the nearest $10 \mathrm{mg}$. The number of embryos and placental scars were recorded. Crown-rump lengths of embryos were measured to the nearest $0.1 \mathrm{~mm}$ with a vernier caliper, and embryos were cleaned and weighed to the nearest $10 \mathrm{mg}$. Ovaries from individuals that bore embryos were fixed in $70 \%$ alcohol and serially sectioned at 6-8 $\mu \mathrm{m}$, stained with haematoxylin and eosin, and examined for corpora lutea (Nixon and McClain, 1975).

The sexual maturity of males was classified according to the histological criteria suggested by Kirkpatrick (1955) and Hoffmann and Kirkpatrick (1956) for gray squirrels (Sciurus carolinensis) and fox squirrels (S. niger). Five stages were identified; infantile (small seminiferous tubules with small or no lumena), prepubertal (most tubules containing primary spermatocytes in the interiors), functional (most tubules with full sperm production), degenerating (early stage-loose primary and secondary spermatocytes, and other cellular debris cluttering the tubules; middle stage-more cellular debris cluttering the tubules, and shrinking tubules; late stage-advanced degeneration with shrinking tubules and disappearing lumina), and redeveloping (forming lumina and layers of developing spermatocytes in tubules). The first two stages were regarded as immature and the rest as adult. Females were classified as adult if any of the following were present: enlarged nipples, placental scars, embryos, or the presence of type seven follicles in the ovary (Pederson and Peters, 1968). Adult females were further classified into three groups based on counts of placental scars; those with no placental scar, with one placental scar, and with two or more placental scars.

Analysis of variance and Student's $t$-tests were performed using SAS (SAS Institute Inc., 1989). Statistical assumptions of these tests were checked and no significant departures were found.

\section{RESULTS}

Sex ratio and body characteristics. - We collected 216 adults (116 males, 100 females) and 65 immatures (23 males, 42 females). With the exception of September, when only two $P$. petaurista were collected, monthly samples ranged from 15 to 36 . Sex ratio of adult squirrels did not deviate from 1:1 ratio $(P>0.05)$. For immature squirrels, our sample was too small to detect the actual sex ratio.

Average body mass of adult females was significantly greater than that of adult males $(1,334$ and $1,260 \mathrm{~g}, P<0.001)$. Except for the uncertainty in September samples, monthly average body mass of adult females were greater than those of males in every month but December (Fig. 1). The differences were greater in January-February and June-August, with significant dif- 


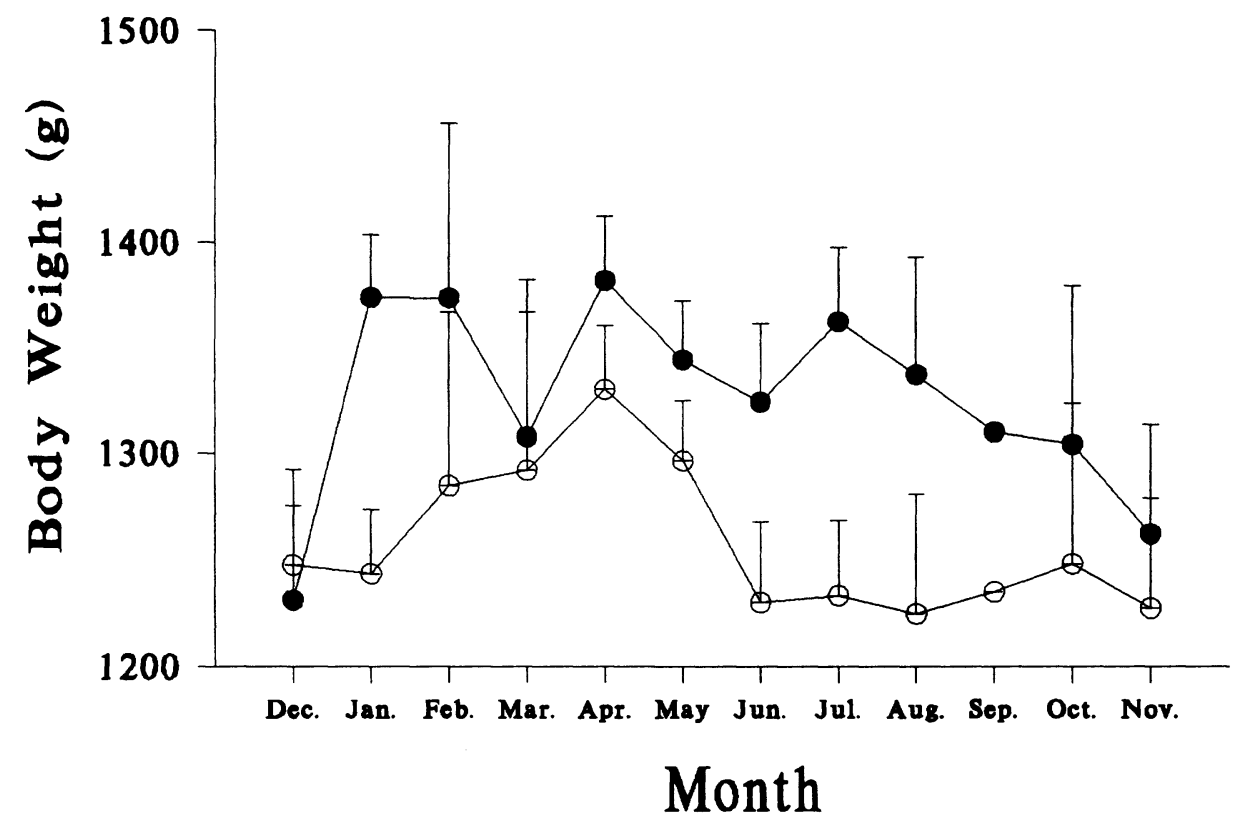

FIG. 1.-Monthly changes (mean $\pm S E$ ) of adult male (open circles) and female (closed circles) body weights of Petaurista petaurista in Sunmin, Taiwan, December 1981-November 1982.

ferences in January and July $(P<0.05)$ after excluding pregnant females from the analysis. Adult males weighed 989-1,569 g, whereas females varied from 1,005 to 1,597 g. Other morphological characters, i.e., lengths of body $(\bar{X}=378 \mathrm{~mm})$, tail $(\bar{X}=$ $459 \mathrm{~mm})$, ear $(\bar{X}=73 \mathrm{~mm})$, hind foot $(\bar{X}=$ $47 \mathrm{~mm})$, and styliform cartilage $(\bar{X}=88$ $\mathrm{mm}$ ), were not significantly different between sexes $(P>0.05)$. There was considerable overlap between immature and adult squirrels in these measurements.

Reproductive cycle of males. - The reproductive development of males showed a seasonal trend (Table 1). Of the 116 adult males, 65 were classified as functional, 48 degenerating, and 3 redeveloping. Functional individuals were found throughout the year, except February (Table 1). Peak abundances of sperm in testes occurred in March-June and October-November, when males were most sexually active. Active spermatogenesis was observed and sperm filled the seminiferous tubules. Immediately following the functional period, some squirrels entered sexual quiescence. Squir- rels with degenerating testes were found from December to February and from June to August. Three developmental stages can be distinguished. Early degenerating testes were found in these months. The middle-degenerating stage followed and occurred in January, February, July, and August. The latedegenerating stage occurred in February, March, and August. The sexual-redeveloping period was short for males as only three individuals were found in this condition in February and August, following the degenerating periods. Testes underwent involution in February and August and recovered from this stage rapidly.

Development of male reproductive organs supported the previous observations. Mean weights of testes and epididymides and diameter of seminiferous tubules showed two major peaks during the year (Fig. 2). Reproductive activity was maximum during March-June and October-November.

Reproductive pattern of females. - Of 100 adult females, 78 showed previous breeding experience. About $52 \%$ of adult females had 
TABLE 1.-Monthly distribution of reproductive status of adult male Petaurista petaurista in Sunmin, Taiwan, December 1981-November 1982. Reproductive status was determined according to the stage of spermatogenesis proposed by Kirkpatrick (1955).

\begin{tabular}{|c|c|c|c|c|c|c|}
\hline \multirow[b]{2}{*}{ Year and month } & \multirow[b]{2}{*}{ Functional } & \multicolumn{3}{|c|}{ Degenerating } & \multirow[b]{2}{*}{ Redeveloping } & \multirow[b]{2}{*}{ Tota } \\
\hline & & Early & Middle & Late & & \\
\hline 1981 December & 2 & 7 & & & & 9 \\
\hline 1982 January & 2 & 2 & 9 & & & 13 \\
\hline February & & 2 & 2 & 4 & 2 & 10 \\
\hline March & 4 & & & 1 & & 5 \\
\hline April & 14 & & & & & 14 \\
\hline May & 9 & & & & & 9 \\
\hline June & 9 & 4 & & & & 13 \\
\hline July & 2 & 1 & 5 & & & 8 \\
\hline August & 5 & 3 & 3 & 5 & 1 & 17 \\
\hline September & 1 & & & & & 1 \\
\hline October & 8 & & & & & 8 \\
\hline November & 9 & & & & & 9 \\
\hline Total & 65 & 19 & 19 & 10 & 3 & 116 \\
\hline
\end{tabular}

only one placental scar, while 22 and $26 \%$ had no placental scars and two or more placental scars, respectively. These groups indicate female age structure in the population. The recruitment rate for the population of females was ca. $22 \%$.

Like males, females exhibited two distinct breeding seasons per year. Paired weights of ovaries showed a bimodal pattern with peaks occurring in January and August (Fig. 3). During the breeding seasons, only $49 \%$ of adult females became pregnant and were found only in winter (December-January) and summer (June-August). Except in February, when the rate was $16.7 \%$, pregnancy rates were $50-57 \%$ for the other months. Based on the occurrence of pregnancy and the development of ovaries, November-January and May-July are the two most sexually active periods for females. The winter breeding season began in late November-early December, and ended in late February, whereas the summer breeding season ran from late May-early June to the end of August-early September. Pregnant females found in December and June had small embryos, whereas those found in later breeding seasons had larger embryos. Based on sizes of embryos, most young were born in January-February and
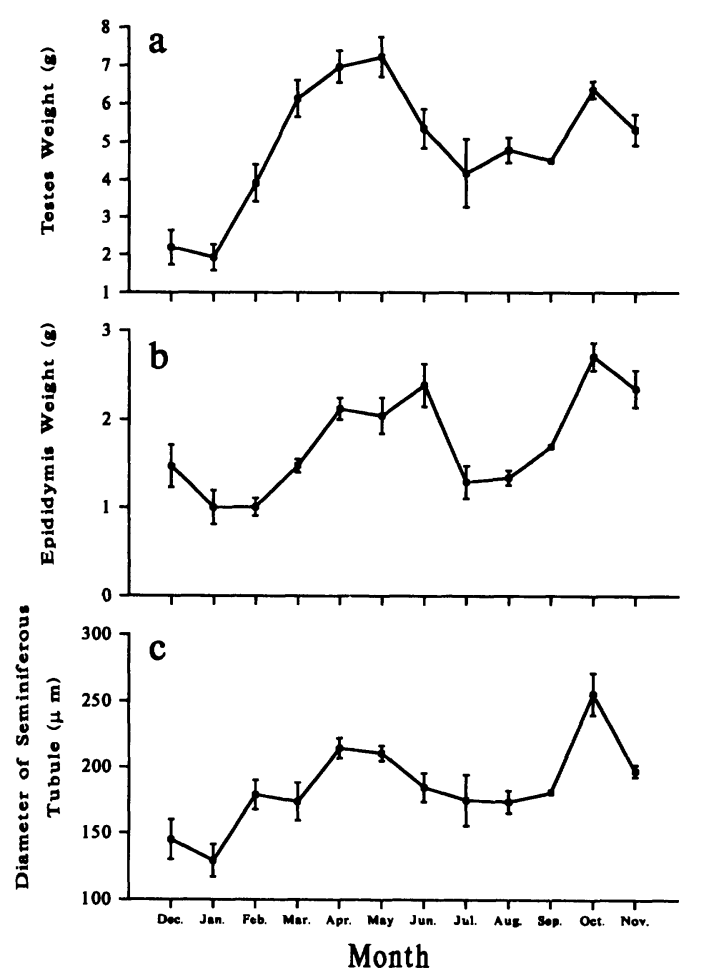

Fig. 2. -Trends of mean $( \pm S E)$ paired testes weight (a), epididymides weight (b), and diameter of seminiferous tubules (c) for adult male Petaurista petaurista in Sunmin, Taiwan, December 1981-November 1982. 


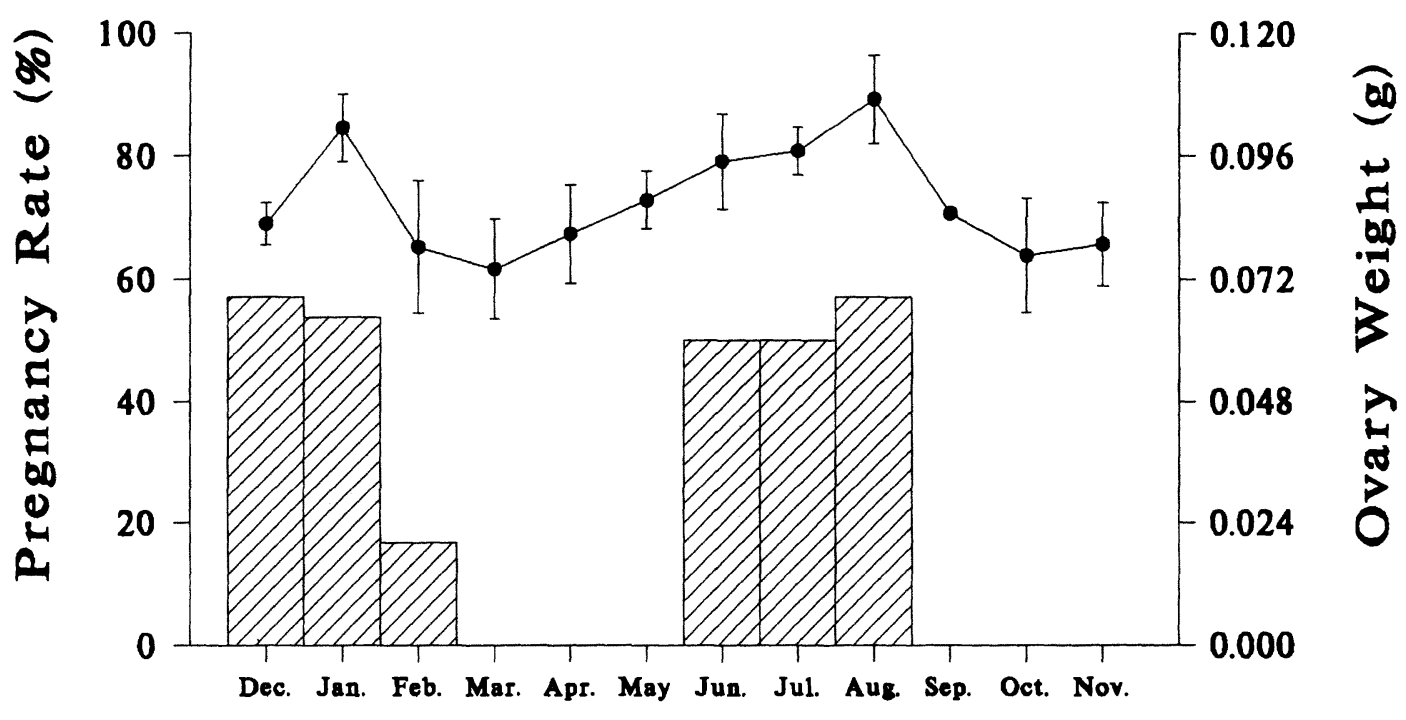

\section{Month}

FIG. 3.-Monthly changes of paired ovarian weight (line, mean $\pm S E$ ) and pregnancy rate (bars) for adult female Petaurista petaurista in Sunmin, Taiwan, December 1981-November 1982.

July-August. Young also were born in September because of the high pregnancy rate and early development of embryos in pregnant females found in August.

Pregnant females did not show greater body dimensions (i.e., body mass, and length of body, tail, hind foot, ear, and styliform cartilage) than the non-breeders $(P>0.05)$. No significant differences in body measurements between breeding females in winter and summer were found $(P>0.05)$.

Only one squirrel had two embryos whereas the others had one, resulting in an average of 1.04 young/litter. Litter sizes were not significantly different between seasons and between first-time and experienced breeders $(P>0.05)$.

The number of corpora lutea varied from one to two, with a mean $( \pm S D)$ of $1.13 \pm$ 0.34 . Of the 24 pregnant females, only two of 27 ova were unsuccessfully implanted. Mortality of embryos after implantation was low; no dead fetuses were observed. Thus, the total prenatal mortality was ca. $7.4 \%$.

Based on pregnancy period and when young were observed in this study and other nearby sites (Lee et al., 1986), we estimated the gestation period for Petaurista to be at least 45 days. The birth weight for $P$. petaurista was $>56.3 \mathrm{~g}$, the largest embryo obtained in this study.

\section{Discussion}

The breeding patterns of Petauristinae vary among species and geographic location. In subtropical Taiwan, $P$. petaurista is a seasonal breeder with two breeding seasons (winter and summer) per year. In temperate areas such as Japan, $P$. leucogenys breeds from spring to autumn (Udagawa, 1954). In North America, the southern flying squirrel (Glaucomys volans) breeds only in spring and autumn (Dolan and Carter, 1977; Geortz et al., 1975; Muul, 1968, 1969; Sollberger, 1943; Sonenshine et al., 1979). In tropical rainforests, such as those in Malaysia, Muul and Lim (1974) found that no particular temporal patterns occurred in Hylopetes lepidus and Pteromyscus pulverulentus.

The average litter size (1.04) found in this study is similar to that previously reported for P. petaurista in Taiwan (Kuroda, 1940) and in Malaysia (Medway, 1978; Muul and 
Lim, 1978). This small litter size also is commonly found in other species of Petaurista; P. magnificus in Nepal (Mitchell, 1979), P. elegans in the Malaysian Peninsula (Muul and Lim, 1978), P. leucogenys in Japan (Udagawa, 1954), and P. alborufus in Taiwan (P. F. Lee and Y. S. Lin, in litt.). The litter size for Petaurista sp. does not seem to be affected by latitude and geographic location and does not follow Lord's (1960) observation of gradual increase of litter size in North American tree squirrels (Sciurus sp.) at higher latitudes.

Muul and Lim (1978) suspected that the small litter size of Petaurista sp. resulted from a low predation rate and was correlated with their high degree of folivory. In Taiwan, predation pressure on $P$. petaurista is relatively low because their natural predators have been eliminated or significantly reduced due to habitat destruction and illegal hunting. The composition of the diet of $P$. petaurista was at least $55 \%$ leaves (Lee et al., 1986). With high leaf contents in the overall diet, mammalian folivores tend to have relatively low metabolic rates (Mc$\mathrm{Nab}, 1978)$. The low metabolic rate is correlated with low reproductive rate $(\mathrm{McNab}$, 1980).

Apparently the breeding pattern of $P$. petaurista was controlled by females. Some male squirrels were capable of breeding each month, except February, as indicated by males with functional testes. However, pregnant females were only found in December-February and June-August. Only about one-half $(49 \%)$ of the adult females became pregnant during the breeding seasons. This low pregnancy rate among females in each breeding season probably is due to few females breeding twice in one year and some females that do not breed at all in a given year. Although our data does not indicate that female $P$. petaurista have only one litter per year, field observations indicate that this is possible. In the field, young were observed foraging with an adult female at ca. 3-4 months of age, when they were ca. $50 \%$ of adult weight (Lee et al.,
1992); this bonding may last for several months (Lee et al., 1986; Muul and Lim, 1978). Lin et al. (1988) reported an unusual case of two female squirrels (mother and offspring) living together in conifer plantations for 16 months and apparently did not breed for the entire period although both showed signs of estrus.

The exact factors behind the timing of breeding season remain unknown. Factors, such as temperature, precipitation, photoperiod, and plant chemicals, have been proposed to account for the onset of breeding seasons in mammals (Herbert, 1977; Jameson, 1988; Reddi and Prasad, 1968). Except for photoperiod and food, factors such as precipitation and temperature cannot explain the breeding pattern in $P$. petaurista, because breeding occurred in both the coldest and warmest seasons as well as in wet and dry seasons. It is reasonable to assume that the reversals in change of daylength may be the most predictable factor that contributes to the observed seasonalbreeding patterns in $P$. petaurista. Many mammalian species show reproductive responses that change with daylength (Bronson, 1989; Jameson, 1988). Muul (1968) found that change in photoperiod was the major contributor for triggering the breeding of $G$. volans. Food is another possible factor in controlling the timing of reproduction in $P$. petaurista, because it relies heavily on vegetation that contains many secondary plant compounds (Jameson, 1988). Further studies on these aspects are necessary.

The increasing differences in body weights between adult male and female squirrels during periods of pregnancy probably are a result of seasonal breeding conditions. Sonenshine et al. (1979) reported that body weights of female $G$. volans increased at the time of the breeding season and male body weights declined during periods of sexual activity. Our results on $P$. petaurista from Taiwan agree with findings for adult sciurids in temperate climates showing a seasonal cycle of body mass; however, for P. petau- 
rista the minimum and maximum weights occur in winter and spring, respectively, in contrast to late winter and autumn as seen for fox squirrels ( $S$. niger-Nixon et al., 1991).

\section{ACKNOWLEDGMENTS}

We thank S. Y. Tu for collecting the specimens and Y. J. Chao for laboratory assistance. A. H. T. Yu provided important references. Earlier drafts of this paper benefited from the suggestions by S. L. Garman and two anonymous reviewers. This work was supported by National Science Council, Republic of China, grant numbers NSC-70-0409-B002-28, NSC-71-04090B002-49, and NSC-73-0201-B002-01.

\section{Literature Cited}

Askins, R. 1977. Family Sciuridae. Pp. 337-387, in Mammals of Thailand (B. Lekagul and J. A. McNeely, eds.). Association for the Conservation of Wildlife, Bangkok, Thailand, $758 \mathrm{pp}$.

Bronson, F. H. 1989. Mammalian reproductive biology. The University of Chicago Press, Chicago, $325 \mathrm{pp}$.

Dolan, P. G., AND D. C. Carter. 1977. Glaucomys volans. Mammalian Species, 78:1-6.

Geortz, J. W., R. M. Dawson, and E. E. Mowbray. 1975. Response to nest boxes and reproduction by Glaucomys volans in northern Louisiana. Journal of Mammalogy, 56:933-939.

HERBERT, J. 1977. External factors and ovarian activity in mammals. Pp. 457-505, in The ovary physiology (L. Zuckerman and B. J. Weir, eds.). Academic Press, New York, 2:1-555.

HoffmanN, R. A., aNd C. M. KirkPatrick. 1956. An analysis of techniques for determining male squirrel reproductive development. Transactions of the North American Wildlife and Natural Resources Conference, 21:346-355.

Honacki, J. H., K. E. Kinman, and J. W. Koeppl (EDS.). 1982. Mammal species of the world: a taxonomic and geographic reference. Allen Press, Inc., and The Association of Systematics Collections, Lawrence, Kansas, 694 pp.

JAMESON, E. W., JR. 1988. Vertebrate reproduction. John Wiley \& Sons, New York, 526 pp.

$\rightarrow$ KirKPaTRICK, C. M. 1955 . The testis of the fox squirrel in relation to age and seasons. American Journal of Anatomy, 97:229-256.

KurodA, M. N. 1940. A monograph of the Japanese mammals. The Sanseido Company, Ltd., Tokyo, Japan, 311 pp. (in Japanese)

LeE, P. F., D. R. ProgulsKe, and Y. S. Lin. 1986. Ecological studies on two sympatric Petaurista species in Taiwan. Bulletin of the Institute of Zoology, Academia Sinica, 25:113-124.

Acade 1993. Spotlight counts of giant flying squirrels Petaurista petaurista and $P$. alborufus in Taiwan. Bulletin of the Institute of Zoology, Academia Sinica, 32:54-61.
Lee, P. F., D. R. Progulske, Y. T. Day, and Y. S. LIN. 1992. Growth pattern of the red-giant flying squirrel Petaurista petaurista in Taiwan. Acta Zoologica Taiwanica, 3:165-170.

LIN, Y. S., AND P. F. LEE. 1986. Debarking on Cryptomeria trees by red-giant flying squirrel (Petaurista petaurista) in Chitou. Quarterly Journal of Chinese Forestry, 19:55-64 (in Chinese, English abstract).

LIN, Y. S., L. Y. WANG, AND L. L. LeE. 1988. The behavior and activity pattern of giant flying squirrels (Petaurista p. grandis). Quarterly Journal Chinese Forestry, 21:81-94 (in Chinese, English abstract).

Lin, Y. S., D. R. Progulske, P. F. Lee, and Y. T. DAY. 1985. Bibliography of Petauristinae (Rodentia, Sciuridae). Journal of Taiwan Museum, 38:4957.

LORD, R. D., JR. 1960. Litter size and latitude in North American mammals. The American Midland Naturalist, 64:488-499.

MCNAB, B. K. 1978. Energetics of arboreal folivores: physiological problems and ecological consequences of feeding on an ubiquitous food supply. Pp. 153162, in The ecology of arboreal folivores (G. G. Montgomery, ed.). Smithsonian Institution, Washington, D.C., $574 \mathrm{pp}$.

1980. Food habits, energetics, and the population biology of mammals. The American Naturalist, 116:106-124.

Medway, L. 1978. The wild mammals of Malaya (Peninsular Malaysia) and Singapore. Second ed. Oxford University Press, Oxford, United Kingdom, $193 \mathrm{pp}$.

Mitchell, R. M. 1979. The sciurid rodents (Rodentia: Sciuridae) of Nepal. Journal of Asian Ecology, $1: 21-28$.

MuUL, I. 1968. Behavioral and physiological influences on the distribution of the flying squirrel, Glaucomys volans. Miscellaneous Publications of the $\mathrm{Mu}-$ seum of Zoology, University of Michigan, 134:1-66.

-1969. Photoperiod and reproduction in flying squirrel, Glaucomys volans. Journal of Mammalogy, 50:542-549.

MuUL, I., AND B. L. Lim. 1974. Reproductive frequency in Malaysian flying squirrels, Hylopetes and Pteromyscus. Journal of Mammalogy, 55:393-400.

. 1978. Comparative morphology, food habits, and ecology of some Malaysian arboreal rodents. Pp. 361-368, in The ecology of arboreal folivores (G. G. Montgomery, ed.). Smithsonian Institution, Washington, D.C., $574 \mathrm{pp}$.

$\rightarrow$ Nixon, C. M., AND M. W. McClain. 1975. Breeding seasons and fecundity of female gray squirrels in Ohio. The Journal of Wildlife Management, 39:426438.

Nixon, C. M., L. P. Hansen, and S. P. Havera. 1991. Growth patterns of fox squirrels in east-central Illinois. The American Midland Naturalist, 125:168172.

NowaK, R. M., AND J. L. Paradiso. 1983. Walker's mammals of the world. Fourth ed. The Johns Hopkins University Press, Baltimore, 1:1-568.

Pederson, T., AND H. Peters. 1968. Proposal for a classification of oocytes and follicles in mouse ovary. Journal of Reproduction and Fertility, 17:555-557. PuDNEY, J. 1976. Seasonal changes in the testis and 
epididymis of the American grey squirrel, Sciurus carolinensis. Journal of Zoology (London), 179:107120.

Reddi, A. H., and M. R. N. Prasad. 1968. The reproductive cycle of the male Indian palm squirrel, Funambulus pennanti Wroughton. Journal of Reproduction and Fertility, 17:235-245.

SAS INSTITUTE INC. 1989. SAS/STAT user's guide, version 6. Fourth edition. SAS Institute Inc., Cary, North Carolina, 1686 pp.

SollbERGER, D. E. 1943. Notes on the breeding habits of the eastern flying squirrel (Glaucomys volans). Journal of Mammalogy, 24:163-173.
Sonenshine, D. E., D. M. LAUER, T. C. WALkeR, AND B. L. ElisBerg. 1979. The ecology of Glaucomys volans (Linnaeus, 1758) in Virginia. Acta Theriologica, 26:363-377.

UdAGAwA, T. 1954. The damage of forests by the giant flying squirrel and a new method of extermination. Bulletin of Governmental Forest Experimental Station, Japan, 68:133-144 (in Japanese, English summary).

Submitted 31 May 1991. Accepted 5 May 1993.

Associate Editor was Joseph F. Merritt. 